\title{
Foreign student guest lecture and Indonesian EFL students' motivation in cross-culture understanding course
}

\author{
Imam Wahyudi Karimullah ${ }^{1 *}$, Sari Kurnia Rahmawati ${ }^{2}$, Elchin Gashimov ${ }^{3}$ \\ 1 Faculty of Teacher Training and Education, Universitas Islam Malang, Indonesia, Faculty of Letter, \\ Universitas Negeri Malang, Indonesia ${ }^{3}$ Moscow City University, Samara Russia \\ 1imamwk@unisma.ac.id, 22sari.kurnia.rahmawati@gmail.com, ${ }^{3}$ elchgash@mail.ru \\ *) correspondence: imamwk@unisma.ac.id
}

\begin{abstract}
This study explores an innovative way to increase students' learning motivation in a cross-culture understanding (CCU) class at an English Language Teaching study program in a private university in Indonesia. The lecturer assigned EFL students to find international students to share their cultures to solve students' lack of motivation in indoor learning activities. From observation, interview, and an online survey to 94 students (four classes), $98.9 \%$ agreed that the international students' guest lecture method could increase EFL students' motivation to learn CCU. The Indonesian lecturer exposed to global culture and international students exposed to Indonesian culture becomes the primary resource for Indonesian EFL students to get insight and inspiration for their intercultural communication and adaptation practices.
\end{abstract}

Keywords: international students; guest lecture; motivation; cross-culture

\section{INTRODUCTION}

Cross-cultural understanding (CCU) class is a course for students to know and understand other countries' cultures. By having CCU, students can avoid cultural shock, misunderstanding, and conflict (Ward et al., 2001). It is crucial because each group's cultural attitudes, ethnicity, region, and country are not necessarily well accepted (Weda \& Atmowardoyo, 2018). For example, one culture tolerates individual perspectives, but the attitude is opposite cultures. The misunderstanding may result in conflict due to the lack of CCU (Weda \& Atmowardoyo, 2018). The learning of CCU includes an understanding of the interaction between two or more different cultures. Fadeeva and Kalinin (2012) argue that CCU cannot run smoothly without intercultural communication skills (Srisermbhok, 2020). It is undoubtedly a challenge for local lecturers to teach the CCU of international culture to understand and contextualize the Indonesian situation. In Indonesia, local lecturers who have studied or lived abroad usually teach CCU classes (Ambarwati et al., 2011). Based on the researchers' observations at an English Language Teaching Program at a private university in Indonesia, CCU class sometimes uses outdoor learning methods. This method invites students to know and experience firsthand events in the field (Asmara et al., 2016; Price, 2016). The students carry out independent learning activities outside the classroom based on the course topic or the learning objectives. They usually work individually or in a group (Asmara et al., 2016). For example, students do outdoor learning activities by observing or interviewing foreigners in public places or tourism sites to learn about international cultures.

This outdoor learning method has both advantages and disadvantages. The students are more interested (Husamah, 2013) and are not bored during the learning process (Amaluddin et al., 2019). Learning resources from the environment are complete and factual (Leadbetter et al., 2019). The nature of learning is meaningful because students experience real or natural learning situations (Asmara et al., 2016). In contrast, the outdoor learning method's weaknesses include that student 
management is complicated and time-consuming (Harris \& Bilton, 2019). Thus, an indoor learning strategy can be an alternative to classroom learning.

After observing a CCU class at a private university in Indonesia, the researchers found that this CCU class used the indoor learning strategy. The lecturer asked students to work in groups. The student groups presented a topic about the culture of other countries. The observation result showed that students paid less attention to the CCU material delivered by their peers. Furthermore, they were also less motivated to participate in class learning activities. Students' lack of motivation in learning is a problem that needs to be solved and is a common problem faced by teachers/faculty members (Astuti, 2013; Dörnyei, 2001). This problem could prevent students from achieving the class learning objectives because they are not fully engaged in the process of learning (Alshenqeeti, 2018). In addition, students are less motivated to learn because of teachers' lack of skill, or their classroom learning activities are tedious and unrewarding (Good \& Brophy, 1994).

The researchers and the CCU lecturer conducted an online survey of Indonesian EFL students taking CCU courses in four different classes in responding to the problem. The survey showed that students were more motivated to learn CCU from foreigners. It is in line with Astuti's (2013) finding that students were more motivated when they learn from native speakers. The researchers then helped the lecturer design and implement the CCU class's Foreign Student Guest Lecture (FSGL) approach. The guest lecture approach creates a positive learning environment for students (Nakano, 2010). Furthermore, a study conducted by Babalola and Agbaje (2019) indicated that using collaborative teaching (involving more than one teacher) results in better student learning outputs. Therefore, considering that students are motivated to learn from native speakers/foreigners (Astuti, 2013), the researchers applied the FSGL approach to increase students' learning motivation in CCU class.

\section{METHODS}

This research took place in an English Language Teaching study program at a private university in Malang, East Java, Indonesia. It involved 94 students from four different classes, and it used a classroom action research approach. First, the researchers began their study with problem identification. Then, they designed, implemented, monitored, and evaluated the alternative classroom learning activity to solve the problem (Gall et al., 2006). Finally, the researchers used observation, interview, and survey to collect descriptive quantitative and qualitative data to assess the implementation step (Gall et al., 2006).

The researchers used classroom action research to solve the students' lack of motivation in CCU class due to indoor learning activity in students' group presentation techniques. The lecturer then designed and implemented the indoor learning activity technique in a foreign guest lecture format with the researchers. Finally, the students invited international students living in Malang to share their cultures in CCU class.

The researchers used classroom observation to see students' motivation in attending foreign student guest lecture (FSGL) and their participation in the class discussion. The researchers used an online survey to see the different learning motivations increase after implementing this alternative (FSGL) approach. The survey asked which method motivated them to learn CCU. It also asked whether they preferred learning CCU from books or students' group presentations from the foreigners (native people of a country) in the class.

\section{RESULTS}

The lecturer assigned Indonesian EFL students into several groups based on the topics to design the classroom learning activity using the foreign student guest lecture (FSGL) method. The topics are the countries' cultures they may visit in the future. These EFL students were assigned to invite international students to present their cultures in CCU class. The foreign student guest lecturers wore their traditional clothing (if possible). They also shared information about foods, traditions, taboos, politeness (do and do not), and the differences between Indonesian and their cultures. These foreign 
guests were international students studying at the same university as the Indonesian EFL students. These multinational students are from Sudan, Yemen, Palestine, Tajikistan, Thailand, Japan, Timor Leste, and the Gambia.

The CCU class is two credits hours, which has 100 minutes per class meeting per week. The class meeting time allocation consisted of three parts: pre-activity (10 minutes), main activity (60 minutes), and post-activity (30 minutes). In the pre-activity, the lecturer reviewed the previous class meeting material. Then, the lecturer gave motivation to the students by explaining the need for CCU learning or the importance of having international communication skills to live overseas. It is crucial to increase their internal motivation in participating in the CCU class.

The main activity was the foreign student guest lecture (FSGL) session, which consisted of 40 minutes for presentation or demonstration by international students and 20 minutes for questions. These international students prepared a PowerPoint presentation that showed pictures and videos of their cultures. In addition, the presenters shared exciting materials contextual to students' needs, such as their family wedding pictures, the snowy situations in their countries, famous foods, and tourism landmarks. From the classroom observation, the lecturer found that the students were enthusiastic and paid attention to the FSGL.

Students could see, in reality, the traditional clothing from other countries, such as when students from Tajikistan, Sudan, and Palestine wore their regular clothes. The Indonesian EFL students participated actively by asking many questions about CCU and the culture shock experienced by these international students while living and studying in Malang, Indonesia. They exchanged ideas, expressed their opinions, interrupted the discussion by asking questions. Even after the discussion time was up, students still wanted to ask more questions.

The last 30 minutes for post-activity was used for assessment, concluding statement from the lecturers, and overview for the next week's topic and assignment. In this activity, the lecturer asked students some essential questions about the issue to check students' comprehension and clarify some misunderstandings from the presentation (if any). Then, the lecturer and the students concluded the importance of intercultural communication skills, strategies to avoid cultural shock, and successfully living in new cultural situations by respecting differences. The CCU class meeting then ended with an overview of the following week's topic and homework.

From the observation and interview, it was clear that the foreign guest lecture method can increase students' internal and external motivation in learning CCU. Moreover, it is in line with an online survey conducted on 94 students participating in this study.

Table 1. Type of Learning Resource that Can Motivate Students in Learning CCU

\begin{tabular}{|c|c|c|}
\hline $\begin{array}{l}\text { Number of } \\
\text { Respondents }\end{array}$ & $\begin{array}{c}\text { Type of Learning } \\
\text { Resources }\end{array}$ & Students' Reasons \\
\hline 94 students & $\begin{array}{l}\text { Native Speakers } \\
\text { (Foreign Guest } \\
\text { Lectures) }\end{array}$ & $\begin{array}{l}\text { Students know more about cultural adaptation directly from native } \\
\text { speakers (foreign guest lecturers). } \\
\text { Class becomes more exciting and attractive. } \\
\text { Students can get accurate and detailed information about } \\
\text { communicating and making social interactions with the } \\
\text { international community. }\end{array}$ \\
\hline One student & $\begin{array}{l}\text { Book, video, scientific } \\
\text { article, and research } \\
\text { paper }\end{array}$ & $\begin{array}{l}\text { Students can learn independently through the learning media. } \\
\text { Students can improve their critical thinking. }\end{array}$ \\
\hline
\end{tabular}

Source: students' comments in the survey

Table 1. shows that almost all students $(98.94 \%)$ said that the FSGL method could motivate them to learn CCU. Thus, this survey supports the claim that FSGL can solve students' lack of motivation in participating in the CCU class.

The lecturer's motivation at the beginning of the class increased students' intrinsic motivation. Students asked questions about international students' experience overseas, weather conditions, learning environment, and social life interactions. It indicates that they have intrinsic motivation to 
study abroad and travel overseas in the future (Hussain et al., 2020; Inngam \& Eamoraphan, 2014; Lo \& Lin, 2020).

The enhancement in students' motivation was also due to external factors such as rewards in CCU class. For example, the guest lecturers bring candies from their countries and taking pictures with the guest lecturers. In addition, exciting learning activities and a conducive learning environment are external factors that motivate them to learn. The external factors were a suitable class schedule, trying traditional dance, and practicing greeting traditions in other cultures.

Students actively learn CCU through the FSGL method because they know different cultures firsthand from the native people owning the culture. In addition, they argued that they get more accurate information from FSGL than from videos, research papers, and scientific articles.

\section{DISCUSSION}

CCU is a knowledge that must be possessed, especially for Indonesian EFL students who plan to continue their studies abroad and international students studying in Indonesia. Knowledge related to CCU can minimize cultural misunderstanding problems during adaptation, communication, and interaction (Lagou \& Zorbas, 2020; Wang, 2020)). Therefore, CCU is very crucial to have. If we do not have it, then conflict among people having different cultures might arise. Thus, research on CCU and students' motivation to learn CCU plays a crucial role in reducing and preventing intercultural communication problems (Aronhime et al., 2003; Chigwendere, 2018).

Based on this study's findings, the researchers confirm that the FSGL method can solve students' motivation to participate in the CCU class. This FSGL method is effective in increasing students' internal and external desire to learn CCU.

\section{Intrinsic and Extrinsic Motivation}

Intrinsic motivation is a strong will to act from within the (internal) individual or a person (Alshenqeeti, 2018; Astuti, 2013). The stronger the intrinsic motivation a person has, the more likely they tried best to achieve goals. The new teaching scenario designed by the CCU lecturer has increased students' motivation in learning. The teaching scenario using the FSGL method by dividing the teaching time allocation into pre-activity, main activity, and post-activity is relevant to the principle of a practical teaching approach proposed by (Merriam et al., 2007).

It is not surprising that the increase in students' intrinsic motivation was due to the Indonesian lecturer's encouragement at the beginning of the class (Salehpour \& Roohani, 2020). Even though it is only 10 minutes time allocation, it provides schemata of the target culture and the importance of learning CCU for students' success. It is in line with the theory of andragogy (adult learning). Adult learners will most likely be more interested in learning practical life skills they need in the future (Merriam et al., 2007). Knowing the importance of CCU for their study abroad goals, international traveling purposes, or overseas job positions will strengthen their intrinsic motivation as EFL students.

FSGL method consisting of presentation and discussion sessions is also helpful to increase students' intrinsic and extrinsic motivation. From the researchers' experience of attending an international guest lecture in Indonesia, students participated more actively in the class discussion with foreign student guest lecturers. This foreign student guest lecturer in CCU class is relatively different from the university, faculty, or department's formal guest lecture. Professionals or faculty members usually deliver a presentation (Belser et al., 2018) in this formal guest lecture format. In this formal situation, EFL students' interaction during the discussion is often limited. Sometimes, students are reluctant to ask their lecturers questions because of embarrassment or lack of confidence to speak in a public or formal forum due to language barrier factors.

In contrast, this FSGL method took place in a smaller classroom with 20 to 25 students per class. The situation was in an informal setting. Most importantly, the guest lecturers are international students studying at the same university as the students. These multinational students are relatively the same age as the EFL students attending the CCU class. There was no difference in their social status; both EFL and international students have the same position. It can be why they feel 
comfortable expressing their opinions or asking foreign student guest lecturers questions (Nakano, 2010). They feel 'safe' to ask questions because the situation is informal, which does not cause embarrassment when making language mistakes or asking easy or even 'silly' questions (Lucero, 2012).

'Safe' to ask questions, and the class schedule was suitable for students (not too early in the morning and not too late in the afternoon) are external factors. This conducive learning environment can increase students' motivation to learn CCU. Besides, exciting learning activities such as trying traditional dance and wearing traditional cloth are fun for students at this age or undergraduate level. It is relevant to the principle of contextual and experiential learning approaches proposed by Dewey (1938). Teachers need to design their learning activities based on students' characters, learning styles, and needs. Students can maximally achieve their learning objectives when they feel more comfortable and have fun learning CCU (Kim, 2018).

Many students argued that foreign student guest lecturers could motivate them to learn CCU. They argued that learning other cultures will be more effective if they know it from the native people of the target countries as the primary source of CCU learning. It is in line with the principle of experiential learning, learning by doing. Students do not just learn theoretical knowledge, but they have the opportunity to practice intercultural communication directly with native people of the target country they know. Students can communicate with them directly in the class.

\section{Intercultural Communication}

Intercultural communication is a process of sending and receiving information between people of different cultural backgrounds (Srisermbhok, 2020; Vo, 2017). It means that when Indonesian students learn foreign languages, they also understand the target language's culture to avoid cultural shock (Sevimel-Sahina, 2020; Umam, 2015). On the other hand, international students could experience cultural shock because of lacking CCU (Noviana, 2014). Thus, CCU is crucial to smoothen the communication process in high and low-context cultures (Nishimura et al., 2008).

High context culture relies heavily on non-verbal cues and is subtle in communication. What the people conveyed does not necessarily mean what they say (Nishimura et al., 2008). In Javanese culture, people communicate with body language. In contrast, low context culture relies heavily on words to convey meaning in communication. People with this culture usually pay attention to what the other person says (Padua \& Smith, 2020).

In practice, communication often faces some obstacles or communication barriers, which is anything that becomes a barrier to effective communication (Lagou \& Zorbas, 2020). An example of an intercultural communication barrier is the head nod. The head's nod in the United States means that the person understands (American Culture, 2021). In contrast, in Japan, the nod does not mean someone agrees but implies that the person is listening. Therefore, by learning from the native people of the target country, we learn verbal and non-verbal communication from the culture's primary sources to ease intercultural communication and social interaction (Wattanavorakijkul, 2020).

\section{Social Interaction}

Social interaction is a dynamic relationship between one individual and another. One individual can influence another individual or vice versa, where there is a reciprocal relationship. The relationship can take place between individual by individual, individual by a group, or group by group (Hawa \& Tilfarloğlu, 2019). The form is cooperative and in the form of action, competition, and dispute. Therefore, within social interaction, there is communication (Sonnenschein \& Ferguson, 2020).

Another goal of $\mathrm{CCU}$ is not only for communication but also for living in a different culture that needs adaptation (Ward et al., 2001). In discussing social interaction between the different cultures, we need to adapt culturally (Lee \& Bailey, 2020). Adaptation is changing ourselves according to the condition of the environment or changing the environment according to individual desires (Singh, 2019). 
In this process, newcomers will often experience difficulty undergoing the adaptation process they faced in their new environments (Padua \& Smith, 2020). It is the most common international students problem (Kholil et al., 2017). To solve this problem, they need CCU (Mukminatun, 2009).

CCU students can gain insight from international students studying in Indonesia to share their countries' living experiences. They also can get a more comprehensive picture of the new environment in the target country for cultural adaptation purposes. The international students can also share the cultural differences between their countries and Indonesia because they have lived and studied in Indonesia. Thus, the foreign guest lecture method can attract students' attention and motivation to learn CCU. Students will feel satisfied by learning from someone who has experienced a cultural adaption process (Kim, 2018). This personal satisfaction (psychological condition) can increase intrinsic motivation (Merriam et al., 2007) in learning CCU.

\section{CONCLUSION}

The use of international students' guest lecture method in CCU class can solve the EFL students' lack of motivation in the CCU class. This method can increase students' intrinsic and extrinsic motivation in learning CCU. The combination role between Indonesian lecturer experience of living overseas and international students residing in Indonesia complements each other in providing students with the real-life context of CCU. Learning CCU from books, videos, articles, and Indonesian lectures is not enough. CCU class needs international students to be the best primary learning resources for intercultural communication and adaptation practices.

The finding of this study can be used by Indonesian lecturers teaching CCU classes. The challenge of using these international students' guest lecture method is the international students' availability in the nearby campus area. The alternative can be conducting an online (Tarihoran, 2020) foreign student guest lecture. Although it is likely possible, the future researcher needs to investigate further the effectiveness of this online foreign guest lecture method for CCU classes.

\section{REFERENCES}

Alshenqeeti, H. (2018). Motivation and Foreign Language Learning: Exploring the Rise of Motivation Strategies in the EFL Classroom. International Journal of Applied Linguistics and English Literature, 7(7), 1. https://doi.org/10.7575/aiac.ijalel.v.7n.7p.1

Amaluddin, L. O., Rahmat, Surdin, Ramadhan, M. I., Hidayat, D. N., Sejati, A. E., Purwana, I. G., \& Fayanto, S. (2019). The Effectiveness of Outdoor Learning in Improving Spatial Intelligence. Journal for the Education of Gifted Young Scientists, 7(3), 717-730. https://doi.org/http://dx.doi.org/10.17478/jegys.613987

Ambarwati, M., Riyani, M., Saputra, M. R., \& Cahyalita, R. D. (2011). The English Department Students' Reasons of Choosing the Native Teacher in Cross-Cultural Understanding (CCU) Course. The 5th International Seminar: Teacher Education in the Era of World Englishes, Satya Wacana Christian University, 82.

https://repository.uksw.edu/bitstream/123456789/535/1/PROS_Maulida-Mila-Muchammad--Rhany_The English Department_Abstract.pdf

American Culture. (2021). Cultural Atlas. https://culturalatlas.sbs.com.au/american-culture/american-culture-do-s-anddon-ts\#american-culture-do-s-and-don-ts

Aronhime, R., Samaan, L. B., Coratti, N., Lazar, C., Flaccus, T. T., McGinnis, J. R., Scammahorn, E., Soderstrom, R., Storti, C., \& Williams, K. (2003). Building Bridges: A Peace Corps Classroom Guide to Cross-Cultural Understanding. United States Peace Corps.

https://permanent.fdlp.gov/websites/peacecorpsgov/www.peacecorps.gov/wws/bridges/bridges.pdf

Asmara, C. H., Anwar, K., \& Muhammad, R. N. (2016). EFL Learners' Perception toward an Outdoor Learning Program. International Journal of Education and Literacy Studies, 4(2), 74-81. https://doi.org/10.7575/aiac.ijels.v.4n.2p.74

Astuti, S. P. (2013). Teachers and Students Perceptions of Motivational Teaching Strategies in An Indonesian High School Context. TEFLIN Journal, 24(1), 14-31. journal.teflin.org/index.php/journal/article/download/152/141

Babalola, J. O., \& Agbaje, F. I. (2019). Collaborative Language Pedagogy And Students' Academic Achievement In English Language In Ekiti State. Advances in Social Sciences Research Journal, 6(11), 36-44. https://doi.org/0.14738/assrj.611.7266

Belser, C. T., Prescod, D. J., Daire, A. P., Cushey, K. F., Karaki, R., Young, C. Y., \& Dagley, M. A. (2018). The Role of Faculty Guest Speakers and Research Lab Visits in STEM Major Selection: A Qualitative Inquiry. Journal of Career and Technical Education, 33(1), 8-26. https://doi.org/10.21061/jcte.v33i1.a1

Chigwendere, F. B. (2018). Towards Intercultural Communication Congruence in Sino-African Organisational Contexts 
[Rhodes University]. In Towards Intercultural Communication Congruence in Sino-African Organisational Contexts (Issue January). https://doi.org/10.5771/9783828871212

Dewey, J. (1938). Experience and Education. Touchstone.

Dörnyei, Z. (2001). Motivational Strategies in the Language Classroom (1st ed.). Cambridge University Press.

Fadeeva, A. A., \& Kalinin, V. F. (2012). the Importance of Cross-Cultural Understanding for Esl Students. Университет Им. В.И. Вернадского, 42(4), 144-151. https://www.tstu.ru/en/science/st/pdf/2012/fadeeva.pdf

Gall, M. D., Gall, J. P., \& Borg, W. R. (2006). Educational Research: An Introduction (8th ed.). Pearson.

Good, T. L., \& Brophy, J. E. (1994). Looking in Classrooms (6th ed.). Harper Collins College Publishers.

Harris, R., \& Bilton, H. (2019). Learning about the past: Exploring the opportunities and challenges of using an outdoor learning approach. Cambridge Journal of Education, 49(1), 69-91. https://doi.org/10.1080/0305764X.2018.1442416

Hawa, H. M., \& Tilfarlığlu, F. Y. (2019). Students' Learning Styles, Self-efficacy and its Correlation with their Social Interaction. Advances in Language and Literary Studies, 10(4), 42. https://doi.org/10.7575/aiac.alls.v.10n.4p.42

Husamah. (2013). Luar Kelas (Outdoor Learning). Prestasi Pustaka Raya Publisher.

Hussain, M. S., Salam, A., \& Farid, A. (2020). Students' Motivation in English Language Learning (ELL): An Exploratory Study of Motivation-al Factors for EFL and ESL Adult Learners. International Journal of Applied Linguistics and English Literature, 9(4), 15-28. https://doi.org/10.7575/aiac.ijalel.v.9n.4p.15

Inngam, P., \& Eamoraphan, S. (2014). A Comparison of Students' Motivation for Learning English as a Foreign Language In Selected Public and Private Schools in Bangkok. Scholar, 6(1), 15-19. https://doi.org/10.1145/3132847.3132886

Kholil, S., Mailin, \& Siregar, I. L. (2017). Komunikasi Antarbudaya Mahasiswa Malaysia dan Indonesia Fakultas Dakwah dan Komunikasi Universitas Islam Negeri (UIN) Sumatera Utara (Intercultural communication between Malaysian and Indonesian students at faculty of Da'wah and Communication of State Isl. AL-BALAGH, 1(2), 175-195. http://jurnal.uinsu.ac.id/index.php/balagh/article/download/1234/989

Kim, Y. Y. (2018). Intercultural Communication: Taking Stock of the Domain. Communication Studies, 69(4), $341-349$. https://doi.org/10.1080/10510974.2018.1472121

Lagou, F., \& Zorbas, V. (2020). Promoting Intercultural Communicative Competence through CLIL in Greek Primary Education. Language Teaching Research Quarterly, 17(April), 1-19. https://doi.org/10.32038/ltrq.2020.17.01

Leadbetter, P., Bussu, A., \& Richards, M. (2019). Emotive outdoor learning experiences in Higher Education: Personal reflections and evidence. Psychology Teaching Review, 25(1), 67-71. https:// files.eric.ed.gov/ fulltext/EJ1216444.pdf

Lee, A. R., \& Bailey, D. R. (2020). Examining South Korean University Students' Interactions with International Students. Asian Journal of University Education, 16(3), 43-58. https://doi.org/10.24191/ajue.v16i3.8622

Lo, C.-F., \& Lin, C.-H. (2020). The Impact of English Learning Motivation and Attitude on Well-Being: Cram School Students in Taiwan. Future Internet, 12(8), 1-15. https://doi.org/10.3390/FI12080131

Lucero, L. (2012). Creating a Safe Learning Environment for All Students: Teaching Strategies for Helping Defiant and Physically Aggressive Students Succeed. Mills College.

Merriam, S. B., Caffarella, R. S., \& Baumgartner, L. M. (2007). Learning in Adulthood: A Comprehensive Guide (Third). Jossey-Bass.

Mukminatun, S. (2009). Developing Cross-cultural Understanding through Sociolinguistic Dissemination: A Practice in Multicultural Education. International Seminar: Multiculturalism and (Language and Art) Education: Unity and Harmony in Diversity, 15. https://eprints.uny.ac.id/1109/1/Developing_Cross-cultural_Understanding_through.pdf

Nakano, H. (2010). Creating a Positive Learning Environment with a Guest Speaker. Library Pbilosophy and Practice. https:/ / digitalcommons.unl.edu/cgi/viewcontent.cgi?article=1317\&context=libphilprac

Nishimura, S., Nevgi, A., \& Tella, S. (2008). Communication Style and Cultural Features in High/Low Context Communication Cultures: A Case Study of Finland, Japan and India. In A. Kallioniemi (Ed.), Undistuva ja kehittyvä ainedidaktiikeka: Ainedidaktinen symposiumi 8.2.2008 Helsingissä. Osa 2 (pp. 783-796). Helsingin Yliopisto. https://people.uwec.edu/degravjr/GEOG-ANTH 351/Articles/NishimuraNevgiTellahighcontextlowcontext.pdf

Noviana, I. (2014). Culture Shock in Intercultural Communication (Qualitative Descriptive Study about Culture Shock for Foreign Students from Palestine and Thailand countries in Muhammadiyah University of Surakarta) [Universitas Muhammadiyah Surakarta]. In Universitas Mubammadiyah Surakarta. http:/ /eprints.ums.ac.id/32503/10/02. Publication.pdf

Padua, J., \& Smith, M. G. (2020). Intercultural Communicative Competence in Teacher Education: Cultural Simulation Insights from Hawai'i. LAFOR Journal of Education, 8(3), 59-76. https://doi.org/10.22492/ije.8.3.04

Price, A. C. (2016). Action Research in Outdoor Learning: Promoting Social and Emotional Learning in Young People with Social Emotional and Behavioural Difficulties (Issue May) [University of Birmingham]. https://etheses.bham.ac.uk/id/eprint/7428/5/Price17EdD.pdf

Salehpour, G., \& Roohani, A. (2020). Relationship Between Intrinsic/Extrinsic Motivation and L2 Speaking Skill Among Iranian Male and Female EFL Learners. Bellaterra Journal of Teaching and Learning Language and Literature, 13(1), 43-59. https://doi.org/10.5565/rev/jtl3.803

Sevimel-Sahina, A. (2020). A Survey on the Intercultural Communicative Competence of ELT Undergraduate Students. Eurasian Journal of Applied Linguistics, 6(2), 141-153. https://doi.org/10.32601/ejal.775793 
Singh, S. (2019). Communicating Cross-Culturally: A Case for Multi-Modal Understanding. Language in India, 19(5), 1-9.

Sonnenschein, K., \& Ferguson, J. (2020). Developing professional communication skills: Perceptions and reflections of domestic and international graduates. Journal of University Teaching and Learning Practice, 17(3), 1-16. https:/ / ro.uow.edu.au/cgi/viewcontent.cgi?article=2030\&context=jutlp

Srisermbhok, A. (2020). Analysis of activities that enhanced students' communication skills and cross-cultural understanding of ASEAN community through english camp: A case study of international inter-cultural expedition camp at universiti Malaysia Sarawak. LEARN Journal: Language Education and Acquisition Research Network, 13(2), 394-413. https:/ / files.eric.ed.gov/fulltext/EJ1258784.pdf

Tarihoran, N. (2020). Using Facebook Group as a Blended Learning Medium in Teaching Cross-Cultural Understanding in Islamic Higher Education. International Journal on Research in STEM Education, 2(1), 13-25. https://doi.org/10.31098/ijrse.v2i1.187

Umam, C. (2015). Close Relationship between Language and Culture and Its Implication on ELT. Jurnal Inovasi.

Vo, Q. P. (2017). Research Papers Rethinking Intercultural Communication Competence in English Language Teaching: A Gap Between Lecturers' Perspectives and Practices in a Southeast Asian Tertiary Context. I-Manager's Journal on English Language Teaching, 7(1), 20-30. https:/ / files.eric.ed.gov/ fulltext/EJ1140320.pdf

Wang, J. (2020). Promoting Cross-Cultural Understanding and Communication: International Chinese Students' Use of Laughter as a Means to Modify the Meaning of Speech. Journal of Educational Issues, 6(2), 1. https://doi.org/10.5296/jei.v6i2.17208

Ward, C., Bochner, S., \& Furnham, A. (2001). The Psychology of Culture Shock (Second). Routledge. https://doi.org/https://doi.org/10.4324/9781003070696

Wattanavorakijkul, N. (2020). Measuring Intercultural Sensitivity of Thai University Students: Impact of Their Participation in the US Summer Work Travel Program. REFLections, 27(1), 81-102. https:// so05.tcithaijo.org/index.php/reflections/article/view/241822/164447

Weda, S., \& Atmowardoyo, H. (2018). Cross-Cultural Competence (CCC) and CrCross-Culturalnderstanding (CCU) in Multicultural Education in the EFL Classroom. The Journal of English as An International Language, 13(2.2), 9-31. http:/ / eprints.unm.ac.id/14863/1/Cross Cultural Competence and Cross Cultural Understanding \%28Sukardi Weda and Haryanto\%29.pdf 